\title{
A Study on the Sustainable Development Strategy of General Education in Private Applied Undergraduate Colleges and Universities
}

\author{
BAI Li-Juan, ${ }^{1, a}$, WANG Yi-Ming ${ }^{2, b}$
}

${ }^{1}$ Center of teaching quality monitoring ,Heilongjiang Finance and Economics Institute,Songbei, Harbin, Heilongjiang,China

${ }^{2}$ Department of civil and surveying engineering, Guilin University of Technology, Fusui, Chongzuo, Guangxi, China

a125567492@qq.com, b3524644192@qq.com

Keywords: General Education,Private applied undergraduate course, Sustainable development, Strategy.

\begin{abstract}
With the development in the transition period of applied undergraduate colleges and universities, the significance of general education and the importance of strengthening the reform of general education are becoming more and more important. Aiming at the objective reality of general education in private applied undergraduate colleges and universities, taking the connotation analysis of general education as the breakthrough point, this paper expounds the problems that need to be solved in the general education of private applied undergraduate colleges and universities, and puts forward the sustainable development strategy.
\end{abstract}

\section{民办应用型本科院校通识教育可持续发展策略探析}

\author{
白丽娟 1 , a 王翌铭 $2, b$ \\ 1 黑龙江财经学院教学质量监控中心, 松北, 哈尔滨, 黑龙江, 中国 \\ 2桂林理工大学南宁分校土木与测绘工程系, 扶绥, 崇左, 广西, 中国 \\ a125567492@qq.com, b3524644192@qq.com
}

关键词：通识教育；民办应用型本科；可持续发展；策略

中文摘要. 随着应用型本科院校在转型期的发展, 通识教育的意义以及加大对通识教育改革 力度的重要性日益凸显。本文针对民办应用型本科院校通识教育开展的客观实际, 以通识教 育内涵的分析为切入点, 阐述了民办应用型本科院校通识教育需要着力解决的问题, 并提出 可持续发展的策略。

\section{1. 引言}

民办高校的发展迄今已有30多年历史，对我国高等教育的普及具有不可忽视的作用。近 年来, 在国家政策的推动和扶持下, 为适应区域经济的发展需要, 民办高校已经进入转型期。 面对当今社会对各类人才的精准需求, 民办应用型本科院校必须加大改革力度, 提高育人质 量。通识教育旨在促进 “人的全面发展” [1], 对学生综合素质的培养至关重要。挖掘通识教 
育的内涵, 对引领教育教学的改革方向、加强课程体系建设、提高人才培养质量具有重要意 义。目前, 民办高校通识教育的开展存在一定误区, 不断深化通识教育的理论研究和实践探 索是民办应用型本科院校转型期攻坚克难的重点课题。

\section{2. 民办应用型本科院校通识教育的内涵分析}

\section{1 概述}

通识教育是英文是 “General Education” 或 “liberal education” 的译名，该词借鉴了中国 传统文化对于 “通” 和 “识” 的解释。也有的学者译作 “通才教育”、“一般教育”, 我国 台湾和相关地区则常译作 “博雅教育” 或 “全人教育” [2]。通识教育是一个相对模糊的概念, 没有普遍认可的确切定义, 但国内外高校通识教育都强调对综合性知识的掌握, 重视跨学科 学习, 致力于促进人的全面发展。为了推动我国通识教育迈向新阶段, 实现协同发展、资源 共享的目的, 一些层次、类别相当的大学分别建立了联盟, 如: 北京大学、清华大学、复旦 大学和中山大学在2015年11月成立了 “大学通识教育联盟” , 将通识课程模块划分成六大领 域、八大课组、七大模块和四大板块，可见其重视程度之高。

\section{2 民办应用型本科院校通识教育的内涵}

关于通识教育的内涵，至今还没有一个确切的、达成一致的表述，诸多教育家都认为通 识教育的内涵是不断发展的, 在不同历史时期和发展阶段, 各个高校都有不同于其他院校的 办学定位和培养目标, 因此各高校的办学决策者和管理者对通识教育内涵的理解和运用也会 不尽相同。我国许多知名大学在借鉴欧美经验的基础上, 已经初步形成了本土化的通识教育 实践路径。由于民办高校建校历史相对短暂，各方面建设有待于进一步完善，转型阶段又迎 来了新的挑战, 因此加强通识教育的顶层设计和综合改革, 对民办应用型本科院校具有重要 意义。从教学管理的角度出发, 构成应用性本科院校通识教育内涵的主要内容如下。

2.2.1 民办应用型本科院校通识教育的目标如下:

通识教育是教育的下位类概念，从属于教育必须以人的培养为目标这个主题。尽管民办 应用型本科院校受到经济社会下就业市场的冲击，受到 “以就业为导向” 思潮的影响，但是 办学者依然要坚定信念, 以促进 “人的全面发展” 为通识教育的目标, 培养和提升学生的综 合素质。

2.2.2 民办应用型本科院校通识教育的内容如下:

通识教育包括除了专业教育之外的所有通识教育课程。这些课程一般分为文科大类和理 工大类，进而又进一步细分为若干个门类、学科。通识教育的知识结构是文理交融、相互交 叉的, 在整合、梳理教育内容时应注重学生综合素质培养和学习效果的最优, 因此要打破传 统的 “灌输式” 教学框架, 将授课内容模块进行重组, 使之与人才培养目标相适应。在创新 创业教育方面, 要通过深化产教融合、校企合作促进学生实践技能的培养和思辨能力的提高。 2.2.3 民办应用型本科院校通识教育的方式如下:

当今科学技术在教育领域的运用, 促进了通识教育平台的信息化建设, 为学生汲取知识、 发展技能、提高素质提供更加有利的成长空间。民办应用型本科院校的通识教育应将传统的 知识讲授主题与学生感兴趣的社会实践活动主题相结合, 为学生提供思考、探究、研讨的空 间, 通过将有形课堂与虚拟课堂相结合、理论知识与实际操作相结合、课堂教授与自主学习 相结合、大班讲座与小班讨论相结合等教育方式实现育人的目的。

2.2.4 民办应用型本科院校通识教育的保障如下:

通识教育的有效开展需要多维度、全方位的教学研究与质量监控体系做保障。转型期民 办应用型本科院校面临的教学改革任务艰巨, 各教学环节还存在着发展不协调的现象, 改革 后教师的角色适应还有待于进一步加强, 因此教学质量的闭环反馈需要更加及时和畅通, 反 
馈内容应更加客观、全面、科学和公允。随着产教融合、校企合作的不断深化, 实践教学质 量保障环节应得到进一步的重视和加强。

\section{3. 民办应用型本科院校通识教育需要着力解决的问题}

大学生在入学前的十多年里, 经历了家庭教育、学校教育和社会教育, 他们的性格、思 想和人格基本趋于成熟, 四年的大学生活对他们上述这些内在的品质不会有太大的改变, 这 是比较客观的事实。但是, 在学生自我的不断完善、知识结构的不断优化、综合能力的不断 提升方面, 还存在着较大的可塑空间。针对当前的现状, 为了让学生通过大学的学习取得更 多的进步，民办应用型本科院校应狠抓通识教育，着力解决通识教育中存在的问题。

\section{1 对通识教育的深度理解缺乏基本的共识}

通过现状调查, 诸多应用型本科院校的决策层、管理层、一线教师及学生对通识教育缺 乏深入的学习, 因此对其内涵和目标的认识模糊, 更谈不上开展策略的达成共识。由于通识 教育思想理念的滞后导致了诸多高校在教育教学环节过于强化地方性、应用性, 从而弱化了 通识教育的 “育人” 职能。例如, 社会上什么是热门产业, 就增设什么专业、开设什么课程 培养什么技术, 一切以就业为导向, 片面加强某些岗位操作技能的培养, 弱化了学生综合素 质的培养, 使教育变得工具化, 最终把学生培养成 “精致的利已主义者”, 违背了 “培养全 面发展的人” 的初衷。民办应用型本科院校的通识教育应立足于助力学生的中长期发展, 去 除功利性。可借鉴国内外通识教育的成功经验，但重在汲取精华，提升认知，弘扬中华民族 的传统文化、彰显民办应用型本科院校特色。

\section{2 通识教育课程的设置缺乏全面、系统的方案}

应用型本科院校的人才培养规格既有别于研究型大学，又有别于高等职业院校，与之相 对应的通识教育应契合自身学科专业结构、生源特点。民办应用型本科院校存在着对通识教 育的认识不够深刻的现状, 导致对通识教育课程设置的理解层面比较肤浅, 认为开设几门通 识课程就可以完成通识教育的任务, 通识教育方案缺乏全面、系统的顶层设计。对于国家行 政部门规定的思政、外语、计算机、心理学、创新创业教育等教育内容, 只是简单的设置了 几门课程, 缺乏必要的培训和指导。个别院校由于没有合适的心理学课程、创新创业课程的 教师, 就把任务摊派到其他专业教师身上, 甚至交给辅导员来完成。由于各方面办学条件的 限制, 学生可选课程的学科范围和课程门数都受到限制, 资源贵乏, 缺乏统筹, 大部分通识 课都是必修课。由此可见, 当前通识教育的课程设置及相应管理机制已经不能适应转型期民 办应用型本科院校的发展需要, 成为制约人才培养的不可忽视的因素。

\section{3 通识教育缺乏可持续发展的管理机制}

当前诸多民办应用型本科院校由于缺乏有效的通识教育管理机制, 例如, 缺乏独立健全 的通识教育组织机构、缺乏精心策划的通识课程体系、缺乏行之有效的管理制度等, 导致管 理者对教师的宣传和引导力度不够、教师对通识课程的深度和广度把握不到位。各个教学单 位开出的通识课程缺乏横向的沟通和交流，导致课程的难易度、学时数、授课方式等存在不 合理的地方。个别教师教学方法陈旧、课堂气氛沉闷, 导致一些学生认为自己学不到东西、 甚至认为通识教育可有可无。为了改变这种不容乐观的现状, 目前已经有一部分民办应用型 本科院校着手进行通识教育管理机制的改革实践, 如成立全校性的通识教育学院、采取大类 招生等, 但是由于学校难以规避全社会对于专业教育的需求, 因此从某中程度上来说, 很多 通识教育的课程只是换了一个名称, 纠其实质还是专业课。可见, 民办应用型本科院校要实 现既定的人才培养目标，面临着对通识教育管理机制加大改革力度、创新实施策略的挑战。 


\section{4. 民办应用型本科院校通识教育可持续发展的策略}

通过前面的分析，笔者认为民办应用型本科院校要实现通识教育的可持续发展，既不能 $\mathrm{j}$ 急躁冒进, 又不能驻足不前, 要结合自己的客观实际有计划、分阶段进行推进。

\section{1 教育教学思想的深入学习和讨论}

当前民办高校的教职员工尤其是广大教师普遍存在着工作量大的现状, 多数人忙于应对 眼前工作任务, 缺乏对教育教学思想的深入学习, 更谈不上实践探索。思路是行为的向导, 通识教育成败的关键在于全体员工对通识教育学习的深度和改革的力度。民办应用型本科院 校应在全校范围内开展以 “通识教育的内涵” “通识教育与专业教育的关系” “通识教育的 课程设置” 等教育教学思想为主题的研学和讨论, 使大家更加清楚地认识到通识教育的本质 和价值取向在于培养 “全面发展的人” ，通识教育不应该受到社会 “功利化” 思潮的影响， 偏离人才培养的轨道。作为应用型人才教育的推进者, 不论什么职位和岗位, 都应该把促进 学生的全面发展作为开展教育工作的第一要务, 要围绕着促进学生的全面发展这个目标, 发 扬 “逢山开道, 遇水架桥” 的精神, 克服改革工作中遇到的各种的困难和阻力, 有计划分阶 段的破解制约通识教育可持续发展的各种难题。

\section{2 通识教育专门管理机构的建立}

在全校上下统一思想的基础上，应建立相对独立的通识教育管理机构，其目的是有利于 整体规划、协调发展、全面监控、及时反馈。国内比较成功的通识教育案例有: 香港中文大 学的通识教育中心、北京大学元培学院、中山大学的博雅学院等 ${ }^{[3]}$ 。其中香港中文大学通识 教育中心为了达到 “全人教育” 的目, 成立了书院, 打破了知识的学科界限, 增进了师生之 间的交流, 其通识教育在专科训练之外均衡而多方面地向学生传授知识, 让学生具备知识和 能力去认识人类社会的重要议题、理念和价值，培养他们有能力在瞬息万变的世界应对不同 的挑战, 做出有见地的判断, 使他们具备终身学习的能力并成为有承担的世界公民。通识教 育的课程设置没有一个标准的模式, 相对独立的通识教育管理机构有利于顶层设计和方案的 实施, 最大程度地避免通识教育课程松散无序、因人设课、教法落后的状态，有力促进通识 教育的发展。

\section{3 多维度通识教育平台的创新构建}

第一，要建立涵盖多维度学科种类的课程体系。民办应用型本科院校应在深刻理解通识 教育内涵的基础上，对现有的和即将增设的课程进行梳理、论证、规划和设计，最后形成一 套合理的、多维度的通识教育课程体系。为了契合通识教育的理念, 课程的设置应涵盖多个 相互交叉、融会贯通的学科。国内比较成功的案例如合肥学院, 通识教育课程的设置分为理 学、工学、文学、经济学、管理学、教育学、艺术学 7 个学科门类, 形成了多学科交叉渗透, 基础学科与应用学科协调发展的格局。不同学科教师之间交流顺畅, 有利于课程体系的不断 优化和完善。第二, 采取多维度通识课程的教育方式。基于当今先进技术在教育领域中的运 用, 学生获取知识的方式是多维度的。通识教育课程的实施可以通过 “有形课堂” 教学、“虚 拟课堂” 学习、学术讲座、分组讨论等方式的共同作用来完成。目前, 诸多民办院校正在积 极引进MOOC课程, 开展在线教育, 海量的教育资源有助于通识教育向培养目标的迈进。多 样化的学习方式便于学生在有限的时间内获取更多的学习资源, 激发他们学习的主动性和积 极性, 提高学习效率和效果。第三, 构建多维度通识教育课程的模块体系。通识教育课程的 设置应以学生的多元化需求为本, 为了便于学生在庞大的课程资源中优化自己的课程学习, 同时也便于教学管理、学分管理及成绩管理, 通识教育的课程通常设置相互联系、交叉渗透 的多维度模块。从对学生学习的强制性角度, 课程模块分为必修课模块和选修课模块; 从课 程的通用性角度, 分为公共课模块和专业课模块; 从学科的门类角度, 又可分为文学社科模 块和理工模块。总之, 通识教育课程模块的设置一定要与本校的人才培养目标相契合。 


\section{4 加强通识教育教师队伍的建设}

通识教育是一种多维度的学生素质教育, 教学内容与当今社会的经济发展和社会形势密 切联系, 学科交叉信息量大, 对教师的综合素质要求比较高。民办应用型本科院校建立专门 的通识教育机构后, 办学特色和发展目标更加明, 教师队伍的人员结构、素质要求的目标因 此也更加清晰。民办高校应根据当前的师资状况, 在人员层次和专业结构方面做好规划, 在 开展校内业务学习和经验交流的同时, 多为教师创造校外培训机会, 使他们开阔眼界, 丰富 思路，提高综合素质和业务水平。

\section{5 通识教育校园文化氛围的营造}

通识教育注重 “全面发展的人” 的培养，鼓励学生在专业知识学习的基础上对跨学科、 多领域的知识进行体验和探索。民办应用型本科院校可以通过开展各种学术知识讲座、读书 学习活动、学习经验交流会、中 (英) 文演讲比赛、文史哲知识竞赛等项目来充实与丰富学 生的课外生活, 促进校园文化的建设。为了让学生进一步感受 “大家风范”, 开阔视野, 陶 冶情操, 增长阅历, 学校如有条件的话可邀请国内外著名专家学者来校讲学。学校中的各种 学会、社团等是培养学生人文素质的重要基地, 学院应增加对这些组织的重视程度, 科学引 导, 规范管理, 使它们发挥出更大的作用。另外, 良好的校际合作、校企合作是提高学生综 合技能的重要途径，应给予大力支持。

\section{6 通识教育质量监控体系的构建}

随着通识教育教学改革的不断深化，与之配套的教学质量评价与监控指标体系应不断充 实和完善。民办应用型本科院校要针对现有的实际情况，既要有效借鉴又不要完全套用同类 院校现有的管理模式, 要研制出一套适合自己本校的、科学的、动态的、操作性强的质量评 价指标体系 ${ }^{[4]}$ 。根据当前民办应用型本科院校督导机制的 “督教” 比较到位、“督学” 和 “督 管” 相对薄弱的实际情况, 该工作的侧重点应从对 “教” 的质量的考察转移到对 “学” 的效 果的考察, 因此教学质量监督与考察的途径应宽泛化, 参评主体应多元化, 评价指标应科学 化, 以保证反馈信息更具真实性、整改措施更具针对性, 推进教学改革的深化, 促进教学质 量的提升。

\section{5. 结束语}

民办应用型本科院校在转型期面临着前所未有的机遇和挑战, 通识教育的效果对人才培 养质量至关重要。因此, 民办应用型本科院校要在深入学习和研究当前教育形势的基础上, 建立真正契合的本院教学目标的、结构合理的多维度通识教育平台, 实现长足发展。

\section{References}

[1] Li Fanjun, Li Ying.Discussion on Teaching Reform of Higher Mathematics in Large Class Enrollment Training Mode, Journal of Higher Correspondence Education(Natural Sciences).vol.19, pp. 236-241, 1988.

[2] Zhong Binglin, Wang Xinfeng, The Connotation of General Education and Its Localization Practice Path.Journal of National Academy of Education Administration, vol.5, pp. 3-9, 2017.

[3] Fan Xinhua, Several Questions that Should be Paid Attention to in General Education in Application-oriented Universities in the Transformation of Higher Education.Western China Quality Education,vol.3, pp. 19+31, 2017.

[4] Bai Lijuan, Xi Xiufang, and Chen Benshi, The Significance of the Characteristics of Private Colleges and Universities to the Construction of Liberal Education. Heilongjiang Education(Theory \& Practice),vol.10, pp. 19-20, 2017. 